\title{
INTERNAL AND EXTERNAL PREDICTORS OF VOCATIONAL HIGH SCHOOL STUDENTS' EMPLOYABILITY: THE ROLE AND FUNCTIONS OF SCHOOL COUNSELORS
}

\section{Dira Inavatin, Alif Muarifah*, Nurul Hidayah \\ *Correspondent Author}

Dira Inavatin

Universitas Ahmad Dahlan

Jalan Pramuka No. 42, Sidikan

Yogyakarta, Indonesia

Email: dirainavatiin@gmail.com

Alif Muarifah

Universitas Ahmad Dahlan

Jalan Ring Road Selatan Yogyakarta,

Indonesia

Email: alif_muarifah@yahoo.co.id

Nurul Hidayah

Universitas Ahmad Dahlan

Jalan Pramuka No. 42, Sidikan

Yogyakarta, Indonesia

Email: nurul.hidayah@psy.uad.ac.id

Page

62-72

\begin{abstract}
The purpose of this study was to depict the vocational high school students' employability. Family support and selfconfidence were examined as predictors that can enhance students' readiness to enter the working world. Ninety-two students of Class XII of a vocational high school participated in this correlational study. They were recruited using cluster random sampling technique. In collecting the data, employability, self-confidence, and family support scales were administered. The collected data were analyzed using multiple regression technique. The result of the study showed that self-confidence and family support are positively correlated with employability, either partially or simultaneously. This study found that self-confidence, as the internal factor, give greater contribution to students' employability. The result of this study could be used as a reference for school counselors to provide guidance and counseling services to enhance students' employability.

Keywords: employability, family support, self-confidence
\end{abstract}

\section{INTRODUCTION}

Employability is a must-have attribute of vocational school students. In addition to influencing one's career progress and professionalism, it helps individuals understand what they need to do to obtain a paid work (Wang \& Tsai, 2014). Employability is viewed as a basic skill required to maintain and perform a good work (Mason, Williams, \& Cranmer, 2009; Azmi, Hashim, \& Yusoff, 2018). Some studies prove that low employability become a barrier for individuals to enter the working world (Pool \& Sewell, 2007; Dollinger \& Lodge, 2020). Hence, industry researchers around the world begin to pay attention to study employability (e.g., Alvarez-Gonzalez, López-Miguens, \& Caballero, 2017; Okay- 
Somerville \& Scholarios, 2017; Qenani, MacDougal, \& Sexton 2014).

However, in Indonesian context, a study on employability is still scarce. This may be accounted for by the fact that career planning has not been considered important to be internalized as early as possible at school level (Ronnås \& Shamchiyeva, 2011). It is important for educational institutions to develop and enhance their students' employability (Jameson, 2008). In many developed countries, employability has become the primary focus of the related parties (Pearce \& Wu, 2018), including school counselors whose functions and duties are closely related to the guidance of students' future career.

Employability allows individuals to obtain a job in the future and manage their careers more optimally (Helens-Hart, 2019; Hess, Jepsen, \& Dries, 2012). It is also proven to enhance business basic skills, such as teamwork skill, communication, selfmanagement, analysis, and critical thinking skills (Lowden, Hall, Elliot, \& Lewin, 2011).

Employability allows individuals to do selfidentification and be aware of their potential careers (Rose, Mclntyre, \& Rimes, 2018). Individuals with good employability may prepare themselves to face market competition and understand the required specialization to apply their knowledge and skills at diverse, dynamic market situation. Furthermore, such individuals possess desires to continue developing special knowledge and skill (Bennett, 2019; De Vos, De Hauw, \& Van der Heijden, 2011). Accordingly, such individuals are capable of taking an appropriate and effective action, exhibit clear purpose, and show willingness to keep learning from experiences, either as individual or social being (Römgens, Scoupe, \& Beausaert, 2020).

Employability reflects how individuals perceive employment opportunities (Julià, Vanroelen, Bosmans, Van Aerden, \& Benach, 2017). It may determine one's jobseeking behaviors, career choice, and job search outcome (Bennett, 2019). It is also related to a job quality (Rzepka, 2018). Individuals are possible to obtain a job that does not suit their skill level, or be trapped in a low-paying, unsustainable work (Ruge \& McCormack, 2017), which does not reflect employability (Hillage \& Pollard,. 2017). Individuals with good employability are able to use their knowledge, skills, and understanding to find a job (Berg, Osher, Same, Nolan, Benson, \& Jacobs, 2017). Such individuals may optimize their competence to work independently in a labor market and develop their potentials to perform a sustainable work (Choi, Jeong, \& Kim, 2019; Van der Heijden, Notelaers, Peters, Stoffers, De Lange, Froehlich, \& Van der Heijde, 2018). Individuals may seek information related to a working environment and identify diverse alternative career potential since they are aware of career options that fit their competence (Froehlich, Beausaert, \& Segers, 2015). When individuals perform such a process, they would be able to minimize job uncertainty or business failure (Chen, Hou, Persson, \& Zhang, 2019).

The presence of vocational school as an institution that prepares middle-skill workers should be evaluated since many vocational school graduates have not been able to meet the demands of the working world in their field (Wijaya, Sudjimat, \& Nyoto, 2016). Indonesia Statistics Bureau (BPS) reports that in February 2018, there were 133.94 million labor force in Indonesia, while the open unemployment rate was reported to reach 6.87 million people (5.13\%). The first and second highest open unemployment rate was found among vocational school and high school graduates, where they contribute up to $20.72 \%$ and $24.02 \%$ of the total open unemployment rate (Sulistianingsih, et al, 2018). They are higher than unemployment rate among elementary school graduates $(14.02 \%)$, junior high school graduates $(18.18 \%)$, associate's degree graduates $(4.3 \%)$, and university graduates. This problem is caused by several reasons, including the inability of vocational school to adjust to the development of the working world, resulting in students' unpreparedness for work. 


\section{4 | PSIKOPEDAGOGIA}

JURNAL BIMBINGAN DAN KONSELING

Vol.9, No.2, December 2020

The problem related to unpreparedness is also faced by one of the vocational schools in Purbalingga. Following the result of interview with the school counselors and teachers, many vocational school graduates find it difficult to obtain a job that fits their skills, which also results in frustration. These graduates' difficulties and frustration may be primarily accounted for by their psychological condition and minimum work preparedness (Baiti \& Munadi, 2014).

To respond to this issue, the present study aimed to extend the understanding of Indonesian vocational school students' employability by considering its internal factor (i.e., self-confidence) and external factor (i.e., family support) as the predictors of employability. Three hypotheses are proposed. First, the present study expects a positive relationship between self-confidence and family support and employability. Second, there is a positive relationship between self-confidence and employability. Third, there is a positive relationship between family support and employability. Family support and self-confidence were examined as predictors that can enhance students' readiness to enter the working world. The result of this study could be used as a reference for school counselors to provide guidance and counseling services to enhance students' employability.

\section{METHODOLOGY}

This correlational study was participated by 92 students of class XII of a vocational school. They were recruited using cluster random sampling technique. Employability, self-confidence, and family support scales were employed to collect the data. In analyzing the data, multiple regression technique was applied.

\section{RESULT AND DISCUSSION}

Some prerequisite tests were conducted, including normality, linearity, and multicollinearity tests. The result of the normality test was displayed in Table 1 . The Kolmogorov-Smirnov Z scores of employability, self-confidence, and family support were 1.12, 0.64, and 0.81 with Asymp. sig. (p) of 0.166, 0.807, and 0.532, respectively. These scores indicate that the recruited sample may represent the population and the data were distributed normally.

Table 1

Normality Test Analysis

\begin{tabular}{lccc}
\hline \multicolumn{1}{c}{ Variable } & $\begin{array}{c}\text { Kolmogorov } \\
\text {-Smirnov Z }\end{array}$ & $\begin{array}{c}\text { Asymp. } \\
\text { sig. }\end{array}$ & $\begin{array}{c}\text { Descrip } \\
\text { tion }\end{array}$ \\
\hline Employability & 1.12. & 0.166. & Normal \\
Self- & 0.64. & 0.807. & Normal \\
Confidence & & & \\
Family support & 0.81. & 0.532. & Normal \\
\hline
\end{tabular}

The next step was to perform linearity test, as displayed in Table 2 , the $F$ value between self-confidence and employability was 18.04, while the $F$ value between employability and family support was 10.06 . The significance levels were 0.000 and 0.003 $(p<0.05)$ This result indicate that each variable possess a linear relationship with employability.

Table 2

Linearity Test Analysis

\begin{tabular}{lccc}
\hline \multicolumn{1}{c}{ Variable } & $\begin{array}{c}\text { F } \\
\text { Linearity }\end{array}$ & sig. & $\begin{array}{c}\text { Descri } \\
\text { ption }\end{array}$ \\
\hline $\begin{array}{l}\text { Self-confidence } \\
\text { and Employability }\end{array}$ & 18.04. & $0,000$. & Linear \\
$\begin{array}{l}\text { Family support } \\
\text { and employability }\end{array}$ & 10.06. & $0,003$. & Linear \\
\hline
\end{tabular}

The last prerequisite test was multicollinearity test, the result of the test is displayed in Table 3. As displayed in the table, the tolerance value of self-confidence and family support was $0.92(>.1)$ and the VIF was $09(<10)$, indicating that there is no multicollinearity.

Table 3

Multicollinearity Test Analysis

\begin{tabular}{|c|c|c|c|}
\hline Variable & Tolerance & VIF & Description \\
\hline Self- & 0.92 & 1.09 & No \\
\hline $\begin{array}{c}\text { Confidenc } \\
\mathrm{e}\end{array}$ & & . & multicollinearity \\
\hline $\begin{array}{l}\text { Family } \\
\text { support }\end{array}$ & 0.92 . & 1.09 & $\begin{array}{c}\text { No } \\
\text { multicollinearity }\end{array}$ \\
\hline
\end{tabular}

The partial relationships of the variables of this study are displayed in Table 4, showing 
the Standardized coefficient between selfconfidence and employability of 0.32 and standardized coefficient between family support and employability of 0.23 . The $p$ values were $0,002(p<0.01)$ and $0.023(p<$ $0,05)$, indicating a partial relationship between each variable and employability.

Table 4

\begin{tabular}{|c|c|c|c|}
\hline \multicolumn{4}{|c|}{ Partial Correlation Analysis } \\
\hline Variable & $\begin{array}{c}\text { Standardiz } \\
\text { ed } \\
\text { Coefficient } \\
\text { s }\end{array}$ & sig. & Description \\
\hline $\begin{array}{c}\text { Self- } \\
\text { Confidence }\end{array}$ & 0.32. & 0.002 . & $\begin{array}{l}\text { Significant } \\
\text { relationship }\end{array}$ \\
\hline $\begin{array}{l}\text { Family } \\
\text { support }\end{array}$ & 0.23 & 0.023 . & $\begin{array}{l}\text { Significant } \\
\text { relationship }\end{array}$ \\
\hline
\end{tabular}

As displayed in Table 5 the $R$ value between self-confidence and family support and employability was 0.45 with significance level of $0.000(p<0.01)$ This result indicates a significant relationship between selfconfidence and family support and employability. In other words, the higher the self-confidence and family support, the higher the employability of an individual. Simultaneously, these variables contribute $20 \%$ of one's employability.

Table 5

Multiple Linear Regression

\begin{tabular}{llll}
\hline Variable & R & $\begin{array}{l}\text { R } \\
\text { Square }\end{array}$ & sig. \\
\hline $\begin{array}{l}\text { Self-confidence and family } \\
\text { support and employability }\end{array}$ & 0.45. & 0.20. & .000 \\
& & &
\end{tabular}

Employability is not a stand-alone variable, rather, it is related to internal and external factors within its development and formation process (Rothwell, Herbert \& Rothwell, 2008; Tentama, Subardjo, \& Abdillah, 2019; Clarke, 2018). While internal factors deal with attributes within individual's self, the external factors cover items outside individuals' self. These two factors were found to individually and simultaneously affect individuals' preparedness for entering the working world. The present study found that students with good self-confidence and family support to work in the field that fits their interest tend to possess higher working opportunity. Accordingly, the first hypothesis of this study is accepted. The finding of the study also supports the second hypothesis, where students with higher self-confidence exhibit higher employability. Self-confidence is fundamentals in learning process, it positively affects the students' participation and progress in learning process (Voitovska \& Tolochko, 2019). Self-confidence represent one's quality, perception that he or she could perform a work in accordance with the standard (Perkins, 2018). Self-confidence may also motivate individuals to seek a job and to reach the expected performance Individuals with higher level of confidence tend to be aware of their strengths and weaknesses (Akdeniz \& Saytekin, 2020). A confident individual feels free to do anything they want, to be responsible for their actions, and has strong urge towards achievements. Individuals with adequate confidence are dare to take risks without worrying about the result (Kanza, 2016).

Self-confidence is one of the internal factors that influence individuals' employability. It is one of the important personality traits to enter business environment (Sitar \& Mihelič, 2018). It is defined as one's recognition of his/her own ability, love, and emotions (Park, 2019). As a wide concept, self-confidence explains the process where individuals prefer to believe in $\mathrm{him} /$ herself to take risks of what he/she has done (Loke, 2005). This concept determines how much efforts an individual will put and how long he/she maintains it to face challenges or difficulties (Perkins, 2018). Industry observers argue that individuals' frequent failure to find a job is caused by low self-confidence. Self-confidence emerges when individuals are aware that they possess abilities required to complete the given tasks successfully (Oney \& Uludag, 2013). Selfconfidence may be reflected by one's high hopes, willingness to work hard to increase working opportunity, and preparedness to face competitions to obtain a job (Yıldırım, 2013). Self-confidence may minimize the anxiety of each action, allowing individuals to be more calm, relaxed, focused on more positive thoughts (Grobbelaar, Duthie, \& 


\section{6 | PSIKOPEDAGOGIA}

JURNAL BIMBINGAN DAN KONSELING

Vol.9, No.2, December 2020

Fanton, 2018). Self-confidence helps individuals to keep up their effort until the purposes are achieved.

Indeed, self-confidence does not always reflects' one's competency. However, it affects one's willingness to keep showing effort and improve their employability (Bucholz, Sue, Yeo, Roman, Bell, \& Sosa, 2011; Dehmer, Amos, Farrell, Meyer, Newton, \& Meyers, 2013). Several studies reported that individuals' competence does not necessarily determine their problemsolving skills, as it was found that individuals with same skills may also reported different achievement (Fang, Huang, Zhang, Huang, Li, \& Yuan, 2018; Pulford, Woodward, \& Taylor, 2018). A confident individual may be dare to act to find a solution related to the working world's problems (Göknar, 2007; White, 2009). Self-confidence is effective in motivating one's self and directing one's behavior to be more positive (Ibrahim, \& Jaafar, 2017). Accordingly, lack of it may result in difficulties in implementing selfpotential (Özkan \& Özen, 2008). Akbari and Shabizada (2020) found that individuals lack participation when facing job opportunities. In the same vein, Krueger (2020) found that individuals are reticent to initiate job search effort while find it difficult to control business environment. They feel helplessness in facing tight business competition (GraceOdeleye \& Santiago, 2019; Irons, \& Lad, 2017). Thus, it is not a surprise when Eraydın and Karagözoğlu (2017) found that low selfconfidence leads to individuals' inability to develop themselves and failure to obtain a job.

One of the external factors affecting individuals' employability includes family support. The present study found that students find it easier to plan their career and prepare themselves for entering the working world when their family provides them with information, guidance, attention, and experience. Thus, the third hypothesis of this study was supported. However, this finding is in contrast with some previous studies (e.g., Adler \& Kwon, 2002; Bridge, 2013) that found that family support does not always provide the required social model such as accommodation and career management. Nevertheless, the importance of family support is inevitable (Masdonati, Massoudi, \& Rossier, 2009).

Family support is found to have both direct and indirect effect on job search success (Van Hoye, Van Hooft, \& Lievens, 2009). Family support may serve as a bank of psychological resources and information that facilitates individuals' decision-making process related to their career (Jiang, 2017). Individuals highly rely on helps from their surroundings, especially family who understand them (Wolff and Moser, 2009). Family's role is inseparable in job search and career development processes (Patel, Salahuddin, \& O'Brien, 2008). As Creed, Fallon, and Hood (2009) argues, family helps individuals to deal with changes in the working worlds by, among others, reducing the required financial burdens, strengthening self-regulation capacity, and finding required information. Without adequate family support, individuals may find it difficult to enter the working world and adjust themselves to various issues in the business world (Bernstrøm, Drange, \& Mamelund, 2019). Family support is defined as the provision of assistance or comfort in order to help individuals to face various biological, psychological, and social stressors (APA, 2007). This process may be facilitated by social activities within the family, such as developing positive relations, giving suggestions, listening to individuals' problem, and cheering up them (Mantai \& Dowling, 2015). Family support may improve individuals' coping strategy, respect, knowledge, and problem-solving skill through actual resources exchanges (Batistic \& Tymon, 2017).

It is a social model that affects one's employability. In the most modest form, individuals can depend on their family's social network (Huggins, 2010). Such a network then provides exclusive accesses to various resources (Forret, 2018). Through family support, individuals may obtain rare information that contains higher success rate 
(Pan, Guan, Wu, Han, Zhu, Fu, \& Yu, 2018). Thus, it can be said that a powerful information network may enhance the job search credibility and make the future seems more predictable (Huggins, Johnston, \& Thompson, 2012; Cenciotti, Alessandri, \& Borgogni, 2017). Individuals may also obtain moral and emotional support, or even services related to their business needs (Adraki, Allotey, \& Yeboah, 2018). Through family emotional support, individuals may enhance their self-control and reduce anxieties related to career uncertainty (Kramer, 2014).

From family social and development perspective, family is responsible for helping its member to enter the working world (Wittekind, Raeder, \& Grote, 2010). Individuals need family support when facing career-related situations such as job preparedness, action implementation, selfexploration, and decision-making process (Difabio \& Kenny, 2012; Rogers, Creed, \& Glendon, 2008). With this regard, family plays a role to navigate its member career transition and student-to-worker status, where unstructured situations are frequently faced (Jiang, 2014). Family support facilitates individuals' positive psychological condition during career exploration (Jiang, 2017). It drives individuals to be more proactive in career-related activities (De Vos, \& Van der Heijden, 2017). When necessary, family would be willing to spend money to smooth the career-learning process ( $\mathrm{Ma}$ and Yeh, 2010). Individuals with family support perceive themselves as more respected, cared, and possess positive self-evaluation, thus allowing individuals to overcome career hindrances easier (Jiang \& Jiang, 2015). Family basically functions to help individuals to grow optimism in career management process (Abebe \& Alvarado, 2018).

At school setting, the role of school counselor is pivotal in preparing students' quality employability so that they can direct themselves to a career that fits their capacity and potential. School counselors play a strategic role related to the formation and development of students' employability, they are obliged to observe the school atmosphere or situation, design programs, provide services, evaluate the programs, and provide preventive, preservative, or curative services.

As an effort in designing guidance and counseling services for enhancing students' employability, school counselors may conduct an assessment, either test- or nontest assessment, to find out their potentials. To deal with students' employability, school counselors may develop a career guidance and counseling service, Through the provision of services and evaluations of career programs, students' employability may be developed, thus allowing them to be more prepared to enter the working world that fits their potential.

\section{CONCLUSION}

Despite the dominant effect of selfconfidence to students' employability, the present study confirms that self-confidence and family support are interrelated. Students would be more prepared to enter the working world when they possess high selfconfidence and family supports that suits their needs.

\section{REFERENCES}

Abebe, M. A., \& Alvarado, D. (2018). Blessing in disguise? Social and institutional determinants of entrepreneurial intentions following involuntary job loss. Journal of Small Business Management, 56(4), 555572.

Adler, P. S., \& Kwon, S. W. (2002). Social capital: Prospects for a new concept. Academy of Management Review, 27(1), 17-40. https://doi.org/10.5465/amr.2002.5922 314.

Adraki, P. K., Allotey, S. K., \& Yeboah, F. K. ( 2018). Social networks and employability in the tamale metropolis of the northern region, of ghana. Journal of Agricultural Economics And Rural Development, 4(1), 357-364.

Akbari, O., \& Sahibzada, J. (2020). Students' self-confidence and its impacts on their learning process. American 
International Journal of Social Science

Research, 5(1), 1-15.

https://orcid.org/0000-0003-2032-

7142.

Akdeniz, H., \& Saytekin, G. N. (2020). Examination of leadership orientations and self-confidence behaviors of faculty of sport sciences students (Kocaeli University Sample). International Journal of Curriculum and Instruction, 12, 233250.

Alvarez-Gonzalez, P., López-Miguens, M. J., \& Caballero, G. (2017). Perceived employability in university students: developing an integrated model. Career Development International Journal, 22(3), 280299. https://doi.org/10.1108/CDI-082016-0135.

APA. (2007). APA dictionary of psychology. American Psychological Association.

Azmi, I. A. G., Hashim, R. C., \& Yusoff, Y. M. (2018). The employability skills of Malaysian university students. International Journal of Modern Trends in Social Sciences, 1(3), 1-14.

Baiti, A. A., \& Munadi, S. (2014). Pengaruh pengalaman praktik, prestasi belajar dasar kejuruan dan dukungan orang tua terhadap kesiapan kerja siswa smk. Jurnal Pendidikan Vokasi, 4(2).

Batistic, S., \& Tymon, A. (2017). Networking behaviour, graduate employability: A social capital perspective. Education + Training Journal, 59(4), 374-388. https://doi.org/10.1108/et-06-20160100.

Bennett, D. (2019). Graduate employability and higher education: Past, present and future. HERDSA Review of Higher Education, 5, 31-61.

Berg, J., Osher, D., Same, M. R., Nolan, E., Benson, D., \& Jacobs, N. (2017). Identifying, defining, and measuring social and emotional competencies. Washington, $D C$ : American Institutes for Research.
Bernstrøm, V. H., Drange, I., \& Mamelund, S. E. (2019). Employability as an alternative to job security. Personnel Review.

Bridge, S. (2013). Reflections on the omission of social capital from enterprise education and business start training. Education + Training Journal, $\quad$ 55(8/9), 899-910. https://doi.org/10.1108/ET-06-20130080.

Bucholz, E. M., Sue, G. R., Yeo, H., Roman, S. A., Bell, R. H., \& Sosa, J. A. (2011). Our trainees' confidence: results from a national survey of 4136 US general surgery residents. Archives of Surgery Journal, 146(8), 907-914. https://doi.org/10.1001/archsurg.2011. 178.

Cenciotti, R., Alessandri, G., \& Borgogni, L. (2017). Psychological capital and career success over time: The mediating role of job crafting. Journal of Leadership \& Organizational Studies, 24(3), 372-384.

Choi, S. J., Jeong, J. C., \& Kim, S. N. (2019). Impact of vocational education and training on adult skills and employment: An applied multilevel analysis. International Journal of Educational Development, 66, 129138.

Chen, X., Hou, T., Persson, K. A., \& Zhang, Q. (2019). Combining theory and experiment in lithium-sulfur batteries: Current progress and future perspectives. Materials Today, 22, 142-158.

Clarke, M. (2018). Rethinking graduate employability: The role of capital, individual attributes and context. Studies in Higher Education Journal, 43(11), 1923-1937.

De Vos, A., De Hauw, S., \& Van der Heijden, B. I. (2011). Competency development and career success: The mediating role of employability. Journal of Vocational Behavior, 79(2), 438-447. https://doi.org/10.1016/j.jvb.2011.05.0 10. 
De Vos, A., \& Van der Heijden, B. I. (2017). Current thinking on contemporary careers: the key roles of sustainable hrm and sustainability of careers. Current Opinion in Environmental Sustainability Journal, 28, 41-50.

Dehmer, J. J., Amos, K. D., Farrell, T. M., Meyer, A. A., Newton, W. P., \& Meyers, M. O. (2013). Competence and confidence with basic procedural skills: the experience and opinions of fourth-year medical students at a single institution. Academic Medicine Journal, 88(5), 682-687. https://doi.org/10.1097/ACM.0b013e31 $828 \mathrm{~b} 0007$.

DiFabio, A., \& Kenny, M. E. (2012). Emotional intelligence and perceived social support among Italian high school students. Journal of Career Development, 39(5), 461-475. https://doi.org/10.1177/089484531142 1005.

Dollinger, M., \& Lodge, J. (2020). Studentstaff co-creation in higher education: an evidence-informed model to support future design and implementation. Journal of Higher Education Policy and Management, 42(5), 532-546.

Eraydın, Ş., \& Karagözoğlu, Ş. (2017). Investigation of self-compassion, selfconfidence and submissive behaviors of nursing students studying in different curriculums. Nurse Education Today, 54, 44-50. http://dx.doi.org/10.1016/j.nedt.2017.0 3.007.

Fang, J., Huang, X., Zhang, M., Huang, F., Li, Z., \& Yuan, Q. (2018). The big-fishlittle-pond effect on academic selfconcept: a meta-analysis. Frontiers in Psychology Journal, 9, 1569.

Forret, M. L. (2018). Networking as a jobsearch behavior and career management strategy. The Oxford Handbook of Job Loss and Job Search, 275.

Froehlich, D. E., Beausaert, S. A., \& Segers, M. S. (2015). Age, employability and the role of learning activities and their motivational antecedents: A conceptual model. The International Journal of Human Resource Management, 26(16), 2087-2101. https://doi.org/10.1080/09585192.201 4.971846.

Grace-Odeleye, B., \& Santiago, J. (2019). A review of some diverse models of summer bridge programs for firstgeneration and at-risk college students. Administrative Issues Journal: Connecting Education, Practice, and Research, 9(1), 35-47.

Grobbelaar, H. W., Duthie, K. R., \& Fanton, E. R. (2018). Effect of a group multimodal anxiety management programme on competitive state anxiety and self-confidence of amateur golfers. South African Journal for Research in Sport, Physical Education \& Recreation, 40(2).

Helens-Hart, R. (2019). The employability self-assessment: Identifying and appraising career identity, personal adaptability, and social and human capital. Management Teaching Review, 4(1), 6-13.

Hess, N., Jepsen, D. M., \& Dries, N. (2012). Career and employer change in the age of the 'boundaryless' career. Journal of Vocational Behavior, 81(2), 280-288.

https://doi.org/10.1016/j.jvb.2011.10.0 09.

Hillage, J., \& Pollard, E. (2017). Employability: Developing a framework for policy analysis. 1998. Disponivel em: http://www. employment-studies. co. uk/reportsummaries/report-summaryemployability-developing-frameworkpolicy-analysis>. Acesso em, 2.

Huggins, R. (2010). Forms of network resource: knowledge access and the role of inter-firm networks. International Journal of Management Reviews, 12(3), 335352. https://doi.org/10.1111/j.14682370.2009.00266.x.

Huggins, R., Johnston, A., \& Thompson, P. (2012). Network capital, social capital 
and knowledge flow: how the nature of inter-organizational networks impacts on innovation. Industry and Innovation Journal, 19(3), 203-232. https://doi.org/10.1080/13662716.201 2.669615

Ibrahim, H. I., \& Jaafar, A. H. (2017). The Outcomes of Work-Integrated Learning Programmes: The Role of Self-Confidence as Mediator between Interpersonal and Self-Management Skills and Motivation to Learn. Pertanika Journal of Social Sciences \& Humanities, 25(2).

Irons, C., \& Lad, S. (2017). Using compassion focused therapy to work with shame and self-criticism in complex trauma. Australian Clinical Psychologist Journal, 3(1), 1743.

Jiang, Z. (2014). Emotional intelligence and career decision-making self-efficacy: national and gender differences. Journal of Employment Counseling, 51(3), 112-124. https://doi.org/10.1002/j.21611920.2014.00046.x.

Jiang, Z. (2017). Social support and career psychological states: an integrative model of person-environment fit. Journal of Career Assessment, 25(2), 219-237.

https://doi.org/10.1177/106907271562 1019.

Jiang, Z., \& Jiang, X. (2015). Core selfevaluation and life satisfaction: The person-environment fit perspective. Personality and Individual Differences Journal, $\quad 75$, 68-73. https://doi.org/10.1016/j.paid.2014.11. 013.

Julià, M., Vanroelen, C., Bosmans, K., Van Aerden, K., \& Benach, J. (2017). Precarious employment and quality of employment in relation to health and well-being in Europe. International Journal of Health Services, 47(3), 389409.

Kanza, D. (2016). The importance of selfconfidence in enhancing students' speaking skill. (Doctoral Dissertation).
Faculty of Arabic Language Arts and Foreign Languages: Mohamed Khider University of Biskra, Biskra, Aljazair.

Kramer, M. W. (2014). Managing uncertainty in organizational communication. Lawrence Erlbaum.

Krueger, N. (2020). Entrepreneurial potential and potential entrepreneurs: 25 years on. Journal of The International Council for Small Business, 1-4. https://doi.org/10.1080/26437015.202 0.1714363 .

Lowden, K., Hall, S., Elliot, D., \& Lewin, J. (2011). Employers' perceptions of the employability skills of new graduates. Edge Foundation.

Ma, P., \& Yeh, C. (2010). Individual and familial factors influencing the educational and career plans of Chinese immigrant youths. The Career Development Quarterly Journal, 58(3), 230-245. https://doi.org/10.1002/j.21610045.2010.tb00189.x.

Mantai, L., \& Dowling, R. (2015). Supporting the PhD journey: Insights from acknowledgements. International Journal for Researcher Development, $6(2)$, 106-121. https://doi.org/10.1108/IJRD-03-20150007.

Masdonati, J., Massoudi, K., \& Rossier, J. (2009). Effectiveness of career counseling and the impact of the working alliance. Journal of Career Development, 36(2), 183-203. https://doi.org/10.1177/089484530934 0798.

Mason, G., Williams, G., \& Cranmer, S. (2009). Employability skills initiatives in higher education: what effects do they have on graduate labour market outcomes?. Education Economics Journal, 17(1), 1-30. https://doi.org/10.1080/096452908020 28315.

Okay-Somerville, B., \& Scholarios, D. (2017). Position, possession or process? Understanding objective and subjective employability during 
university-to-work transitions. Studies in Higher Education Journal, 42(7), 1275-1291.

https://doi.org/10.1080/03075079.201 5.1091813.

Oney, E., \& Uludag, O. (2013). Classification of self-confidence: Is general selfconfidence an aggregate of specific self-confidences?. International Conferance on Service Management. Cyprus.

Özkan, İ. A., \& Özen, A. (2008). The relation between submissive behaviours and self esteem state among nursing students. TSK Koruyucu Hekimlik Bülteni, 7(1), 53-58.

Pan, J., Guan, Y., Wu, J., Han, L., Zhu, F., Fu, X., \& Yu, J. (2018). The interplay of proactive personality and internship quality in Chinese University Graduates' job search success: The role of career adaptability. Journal of Vocational Behavior, 109, 14-26.

Park, J. (2019). The qualities criteria of constructive play and the teacher's role. Turkish Online Journal of Educational TechnologyTOJET, 18(1), 126-132.

Patel, S. G., Salahuddin, N. M., \& O'Brien, K. M. (2008). Career decision-making self-efficacy of Vietnamese adolescents: The role of acculturation, social support, socioeconomic status, and racism. Journal of Career Development, 34(3), 218-240. https://doi.org/10.1177/089484530730 8488.

Pearce, P. L., \& Wu, M. Y. (2018). Entertaining international tourists: An empirical study of an iconic site in China. Journal of Hospitality \& Tourism Research, 42(5), 772-792.

Perkins, K. E. (2018). The integrated model of self-confidence: Defining and operationalizing self-confidence in organizational settings. (Doctoral Dissertation). College of Psychology and Liberal Arts: Florida Institute of Technology, Melbourne, Florida.

Pool, L. D., \& Sewell, P. (2007). The key to employability: developing a practical model of graduate employability. Education Training Journal, 49(4), 277-289.

https://doi.org/10.1108/004009107107 54435.

Pulford, B. D., Woodward, B., \& Taylor, E. (2018). Do social comparisons in academic settings relate to gender and academic self-confidence?. Social Psychology of Education Journal, 21(3), $677-$ 690. https://doi.org/10.1007/s11218018-9434-1.

Rose, A., Mclntyre, R., \& Rimes, K. A. (2018). Compassion-Focused Intervention for Highly Self-Critical Individuals: Pilot Study. Behavioural and Cognitive Psychotherapy Journal, 46(5), 583-600.

Rzepka, S. (2018). Labor market returns to college education with vocational qualifications. Education Economics Journal, 26(4), 411-431.

Sitar, A. S., \& Mihelič, K. K. (2018). The interplay of expatriates' psychological and social capital for knowledge transfer 1. Economic and Business Review for Central and South-Eastern Europe Journal, 20(2), 195-306.

Qenani, E., MacDougall, N., \& Sexton, C. (2014). An empirical study of selfperceived employability: Improving the prospects for student employment success in an uncertain environment. Active Learning in Higher Education Journal, 15(3), 199213.

https://doi.org/10.1177/146978741454 4875.

Rogers, M. E., Creed, P. A., \& Glendon, A. I. (2008). The role of personality in adolescent career planning and exploration: A social cognitive perspective. Journal of Vocational Behavior, 73(1), 132-142. https://doi.org/10.1016/j.jvb.2008.02.0 02.

Römgens, I., Scoupe, R., \& Beausaert, S. (2020). Unraveling the concept of employability, bringing together research on employability in higher 


\section{2 | PSIKOPEDAGOGIA}

JURNAL BIMBINGAN DAN KONSELING

Vol.9, No.2, December 2020

education and the workplace. Studies in Higher Education Journal, 45(12), 2588-2603.

Ronnås, P., \& Shamchiyeva, L. (2011). Employment diagnostic analysis: Maluku, Indonesia. International Labour Organization.

Rothwell, A., Herbert, I., \& Rothwell, F. (2008). Self-perceived employability: Construction and initial validation of a scale for university students. Journal of Vocational Behavior, 73(1), 1-12. https://doi.org/10.1016/j.jvb.2007.12.0 01.

Ruge, G., \& McCormack, C. (2017). Building and construction students' skills development for employabilityreframing assessment for learning in discipline-specific

contexts. Architectural Engineering and Design Management Journal, 13(5), 365-383.

Sulistianingsih, dkk. (2018). Peran minat kerja dan prestasi belajar terhadap kesiapan kerja siswa SMK. Jurnal Media Komunikasi Pendikan Teknologi dan Kejuruan, 5(2), 51-60.

Tentama, F., Subardjo., \& Abdillah, M. H. (2019). Motivation to learn and social support determine employability among vocational high school students. International Journal of Evaluation and Research in Education, $\quad 8(2), \quad$ 237-242. http://doi.org/10.11591/ijere.v8i2.1818 8.

Van der Heijden, B. I., Notelaers, G., Peters, P., Stoffers, J. M., De Lange, A. H., Froehlich, D. E., \& Van der Heijde, C. M. (2018). Development and validation of the short-form employability fivefactor instrument. Journal of Vocational Behavior, 106, 236-248.

Van Hoye, G., Van Hooft, E. A., \& Lievens, F. (2009). Networking as a job search behaviour: A social network perspective. Journal of Occupational and Organizational Psychology, 82(3), 661-682.
https://doi.org/10.1348/096317908X36 0675.

Voitovska, O., \& Tolochko, S. (2019). Lifelong learning as the future human need. Philosophy \& Cosmology Journal, (22), 144-151.

Wang, Y. F., \& Tsai, C. T. (2014). Employability of hospitality graduates: student and industry perspectives. Journal of hospitality \& tourism education, 26(3), 125-135. https://doi.org/10.1080/10963758.201 4.935221.

White, K. (2009). Self-confidence: A concept analysis. Nursing Forum Journal, 44(2), 103-114. https://doi.org/10.1111/j.17446198.2009.00133.x.

Wittekind, A., Raeder, S., \& Grote, G. (2010). A longitudinal study of determinants of perceived employability. Journal of Organizational Behavior, 31(4), 566586. https://doi.org/10.1002/job.646.

Wolff, H. G., \& Moser, K. (2009). Effects of networking on career success: A longitudinal study. Journal of Applied Psychology, 94(1), 196-206. https://doi.org/10.1037/a0013350.

Yıldııı, F. (2013). Adaptation of sportive continuous self-confidence subscale and investigation of sportive continuous self-confidence among students in secondary schools. (Master Thesis). Department of Physical Education and Sports: Mersin University, Turkey. 